\title{
Proteomic analysis of an Aedes albopictus cell line infected with Dengue serotypes 1 and 3 viruses
}

Sirilaksana Patramool ${ }^{1,2}$, Pornapat Surasombatpattana ${ }^{1}$, Natthanej Luplertlop ${ }^{2}$, Martial Sévéno ${ }^{3}$, Valérie Choumet $^{4}$, Frédéric Thomas ${ }^{1}$ and Dorothée Missé ${ }^{*}$

\begin{abstract}
Background: Proteomic analysis was performed to identify proteins regulated during infection by Dengue serotypes 1 and 3 in an Aedes albopictus cell line. The potential of these viruses to cause severe disease at primary infection is of interest although few studies have been performed with these two Dengue serotypes.

Results: The most relevant observation of our study is the significant overexpression of proteins involved in the cellular stress response and the glycolysis pathway after 48 hours of infection. Viral infection activates the translation of some host genes, which may result in stress due to responses involving unfolded proteins.

Conclusions: Therefore, the oxidation reduction and glycolytic mechanisms could participate in the antiviral response against Dengue virus. The results of our study should help to improve our knowledge of the virus-mosquito interaction at a cellular level with the aim of designing efficient strategies for the control of Dengue virus.
\end{abstract}

\section{Background}

Aedes aegypti (Diptera, Culicidae) is considered the major vector for Dengue infection outbreaks worldwide [1]. Aedes albopictus (Diptera, Culicidae) is a less efficient vector for this virus, although it was involved in Dengue outbreaks in Japan, Seychelles, Hawaii, and Reunion Island [2]. The recent invasion of this second vector into America, Europe, and Africa could increase the transmission of arboviruses in tropical as well as temperate regions [3,4]. Dengue virus (DENV) can cause several clinical forms, ranging from an asymptomatic disease to severe Dengue hemorrhagic fever (DHF) or Dengue shock syndrome [5]. The World Health Organization estimates that 2.5 billion people live in more than 100 endemic areas where DENV can be transmitted [5]. DENV dramatically expands each year into new territories $[6,7]$ as a consequence of combined factors such as the rapid and easy mobility of human populations, the distribution of mosquito vectors, and the lack of herd immunity in unexposed populations [8].

There are four serotypes of DENV (DENV-1 to DENV-4) that differ by their antigenic groups. Each

\footnotetext{
* Correspondence: dorothee.misse@ird.fr

'Laboratoire Maladies Infectieuses et Vecteurs: Ecologie, Génétique, Evolution, Contrôle., UMR 5290 CNRS/IRD/UM1, Montpellier, France Full list of author information is available at the end of the article
}

group can be divided into three to five different genotypes. Therefore, it is difficult to take into consideration all these factors when trying to determine the mechanisms involved in the pathogenesis of the virus. Many researches have focused on DENV-2, which provokes the most severe form of Dengue in secondary infection $[8,9]$, but types 1 and 3 have recently been found as new emerged types in Europe and Africa [2,10]. The report of two autochthonous DENV-1 infected persons in metropolitan France in September 2010 is a recent example of the introduction and local transmission of DENV outside its traditional area [2]. Many studies have reported that DENV-1 and DENV-3 cause severe disease at primary infection while DENV-2 and DENV-4 are frequently involved in Dengue outbreaks at secondary infection [11-14].

Because there is no available antiviral treatment or vaccine to cure or prevent DENV, other approaches are needed to fight and control the virus. A good understanding at the molecular level of the virus-mosquito interaction should help with the design of efficient strategies for the control of DENV. Mosquito cell infection is a part of the Dengue viruses' life cycle that is poorly understood. In this study, we compared the proteome of infected and non-infected cultures of the C6/36 Ae. albopictus cell line using two-dimensional differential in-gel 
electrophoresis (2D-DIGE) to examine modulated proteins of infected mosquito cells. We chose DENV-1 and DENV-3 as study models because of their remarkable capacities to induce severe disease with the first infection. Furthermore, travelers have more chance to develop DENV-1 or DENV-3 infection when they live in nonendemic areas and have never been in contact with the virus $[2,10,15]$. This could be due to the lack of herd immunity in this human population [16].

\section{Results}

\section{2-D-DIGE analysis of dengue infected and non-infected} C6/36 Ae. albopictus cells

C6/36 cells were collected $48 \mathrm{~h}$ after infection with DENV1 , DENV-3, or a control (hereafter "mock infected"). We chose to use $48 \mathrm{~h}$ post infection because it was previously shown that this time corresponded to the exponential phase for both DENV-1 and DENV-3 productions in C6/ 36 cells [17]. We assumed that most cells are infected by the virus at this time. Proteins were prepared and labelled to run on 2D-DIGE. About 1500 spots were detected on $24 \mathrm{~cm}$ Immobiline DryStrip, pH 3-10 NL, followed by SDS-PAGE electrophoresis (Figure 1). Our analysis of gel images, quantification of protein expression, and statistical analysis revealed 22 differentially expressed protein spots. Notably, the mosquito cells infected by DENV-1 or DENV-3 showed similar patterns of protein expression (i.e same trend for the expression of proteome) compared to mock infected cells. The protein expression patterns can be divided into three groups according to the level of protein expression (Table 1). Group I includes 2 proteins that are up-regulated in cells infected by DENV-1 compared with their expression in DENV-3 infected and mockinfected cells (Table 1). The second group is composed of 15 proteins, the expression of which is up-regulated in DENV-3 infected cells compared to DENV-1 infected and mock-infected cells (Table 1). In these two groups, the protein expression is higher in DENV-infected than in the mock-infected cells (Table 1). The third group has 5 proteins that are up-regulated in mock-infected cells compared with the DENV-infected ones (Table 1).

\section{Identification of candidate proteins}

Twenty two spots were identified as being 13 different proteins by Matrix assisted laser desorption ionisation time-of-flight mass spectrometry (MALDI-TOF MS) (Table 2). Several of these spots were identified as the same protein. These different forms of a protein could be due to post-translational modifications like glycosylation, phosphorylation, acetylation, or protein degradation.

Nine of the 13 identified proteins belong to the groups 1 and 2, i.e., those proteins that are up-regulated in infected conditions. Notably, five of these were enzymes involved in the glycolysis pathway. These included enolase, phosphoglycerate mutase, triosephosphate isomerase, fructose-bisphosphate aldolase, and glyceraldehyde-3-phosphate dehydrogenase (GAPD). The significant upregulation of these enzymes in virus-infected cells might indicate that the virus disturbs glucose metabolism in host cells [18]. The four remaining overexpressed proteins were quinine oxidoreductase, chaperonin-60kD, and two putative uncharacterized proteins (Q17AU4_AEDAE and BOWBF6_CULQU). Quinone oxidoreductase is implicated in oxidation-reduction reactions; chaperonin- $60 \mathrm{kD}$ and Q17AU4_AEDAE are involved in protein folding process; and BOWBF6_CULQU has no known function.

The four overexpressed proteins in mock-infected cells were procollagen-lysine 2-oxyglutarate 5-dioxygenase (PLOD), calponin, ethanolamine-phosphate cytidylyltransferase, and aconitase. PLOD is involved in the oxidation-reduction necessary for the biosynthesis of collagen [19]; calponin inhibits the ATPase activity of smooth muscle myosin [20]; ethanolamine-phosphate cytidylyltransferase participates in biosynthesis specifically by transferring phosphorus-containing nucleotide groups [21]; and aconitase is a tricarboxylic acid cycle enzyme that has a role in the regulation of iron metabolism [22].

\section{Discussion}

DENV usually induces apoptosis in infected mammalian cells but causes less damage in mosquito cells [23]. The mechanisms involved in the interaction between DENV and insect cells have been described in recent studies [9,24-27], but these only concern the DENV-2 virus serotype. DENV-1 and DENV-3 have been less studied than DENV-2 and DENV-4. DENV-1 and DENV-3 have been found to cause DHF at first infection [12]. This finding as well as the recent report of DENV-1 introduction in France [2] and the re-emergence of DENV-3 in Sudan [28] attract our interest in these two virus serotypes. In this study, we compared the proteomes of C6/36 Ae. albopictus cells infected and non-infected with DENV-1 and DENV-3.

Cells infected with DENV-1 and DENV-3 exhibited many proteins that were differentially expressed compared to the mock-infected cells. These data may reveal cellular stress due to viral infection. In response to this stress, mosquito cells utilize antioxidant reactions combined with increased energy production to cope with the virus. The up-regulation of chaperone proteins in infected cells might be due to stress in the endoplasmic reticulum (ER) induced by viral infection; ER is where proteins are synthesized. Only proteins that are correctly folded by ER chaperones are transported to the Golgi apparatus. Misfolded and unfolded proteins lead to ER stress. Eukaryotic cells up-regulate ER chaperones and establish the cytoprotective mechanism known as the unfolded protein response (UPR) to degrade the unfolded protein [29]. Molecular 


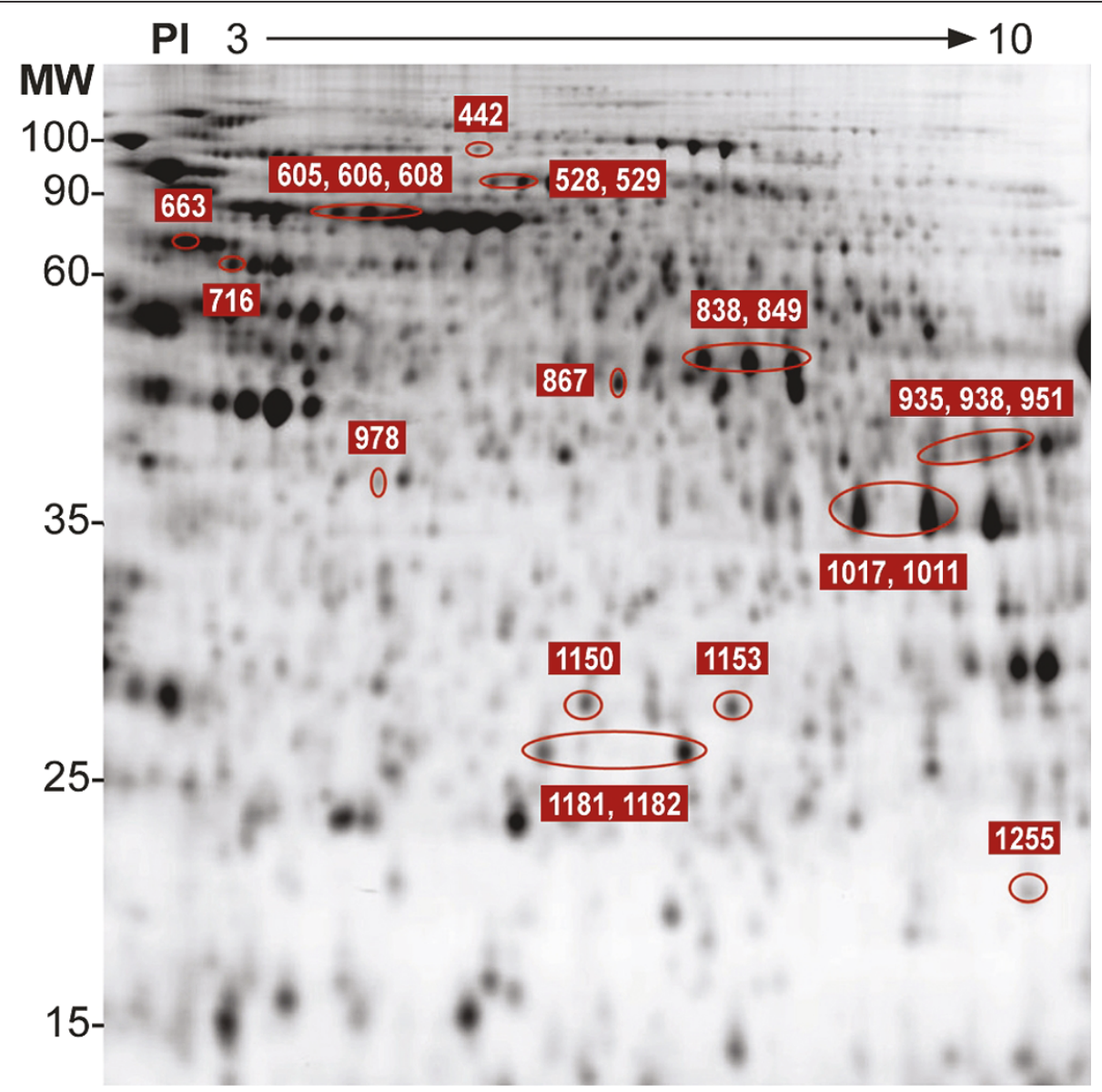

Figure 1 2D-DIGE synthetic gel of Ae. albopictus C6/36 cells infected or not with DENV-1 and DENV-3. Proteins were run with a pl scale of 3-10. Protein spots differentially expressed (numbered spots) were identified by MALDI-TOF MS. The molecular weight scales are indicated in the figure.

chaperones are involved in preventing both newly synthesized polypeptide chains and assembled subunits from aggregating into nonfunctional structures [30]. Chaperone proteins were shown to interfere with virus assembly and replication in Ae. albopictus cells infected with Mayaro virus, and thus protect the cells from injury during viral infection [31]. Furthermore, the expression of Hsp90 was required for the activity of hepatitis $B$ virus reverse transcriptase [32].

Interestingly, it has been reported that acute infection of mammalian cells with several types of viruses often results in the induction of heat-shock protein expression [33]. The up-regulation of chaperone proteins 24 hours after infection with DENV was previously reported [23]. These studies support our findings with infected cells, which show two up-regulated proteins involved in protein folding biological process: chaperonin-60kD (Q16PM9_AEDAE) and one putative uncharacterized protein identified by mass spectrometry as being from Culex quinequefasciatus (B0WBF6_CULQU). These proteins belong to the heat-shock protein families Hsp60 and Hsp70, respectively.

Cells require a chaperone function to prevent or correct misfolded or unfolded proteins created by environmental stress. These chaperone proteins aid protein folding in different ways. Hsp60 is a mitochondrial chaperone that generally assists the carrying and refolding of proteins from the cytosol to mitochondria [34]. Many Hsp70 chaperones could surround an unfolded substrate to stabilize it and prevent aggregation until the unfolded molecule folds properly, after which the Hsp70 chaperones will lose affinity for the molecule and diffuse away [34,35]. Hsp60 and Hsp70 could induce mitochondrial UPR in the same way as the ER stress response [29].

The modulation of chaperone-associated proteins could protect cells from apoptosis, as does the overexpression of calreticulin, which is a $\mathrm{Ca}^{2+}$-binding chaperone protein [36]. These findings suggest that the activation of these two chaperone proteins in infected cells due to oxidative stress could induce UPR to cope 
Table 1 Differential protein expression between an uninfected and DENV-infected C6/36 Ae.albopictus cell line

\begin{tabular}{|c|c|c|c|c|c|c|}
\hline \multirow[t]{2}{*}{ Spot $\mathrm{N}^{\circ}$} & \multirow[t]{2}{*}{ ANOVA (p) } & \multirow[t]{2}{*}{ Fold } & \multicolumn{3}{|c|}{ Average Normalized Volumes } & \multirow[t]{2}{*}{ Functional annotation } \\
\hline & & & DENV 1 & DENV 3 & CONTROL C6-36 & \\
\hline \multicolumn{7}{|c|}{ Group I: DV1>DV3>C } \\
\hline 978 & $8.98 \mathrm{E}-13$ & 2.6 & 1.594 & 1.53 & 0.605 & Putative uncharacterized protein \\
\hline 663 & $2.88 \mathrm{E}-09$ & 2.6 & 1.604 & 1.183 & 0.613 & Quinone oxidoreductase \\
\hline \multicolumn{7}{|c|}{ Group II: DV3>DV1>C } \\
\hline 838 & $9.00 \mathrm{E}-11$ & 4.3 & 1.114 & 1.79 & 0.421 & Enolase \\
\hline 849 & $5.34^{\mathrm{E}}-13$ & 3.3 & 1.395 & 1.947 & 0.584 & Enolase \\
\hline 606 & $3.16 \mathrm{E}-07$ & 3.2 & 1.111 & 1.323 & 0.417 & Putative uncharacterized protein \\
\hline 1153 & $6.09 \mathrm{E}-10$ & 2.9 & 1.235 & 1.584 & 0.549 & Phosphoglycerate mutase \\
\hline 608 & $3.21 \mathrm{E}-07$ & 2.8 & 1.305 & 1.429 & 0.507 & Putative uncharacterized protein \\
\hline 1181 & $1.50 \mathrm{E}-10$ & 2.7 & 1.18 & 1.559 & 0.57 & Triosephosphate isomerase \\
\hline 935 & $5.15 \mathrm{E}-10$ & 2.7 & 1.251 & 1.569 & 0.579 & Fructose-bisphosphate aldolase \\
\hline 1150 & $5.47 \mathrm{E}-11$ & 2.5 & 1.237 & 1.551 & 0.608 & Phosphoglycerate mutase \\
\hline 605 & 2.57E-06 & 2.3 & 0.898 & 1.094 & 0.483 & Putative uncharacterized protein \\
\hline 716 & $3.46 \mathrm{E}-05$ & 2.3 & 0.962 & 1.148 & 0.489 & Chaperonin-60kD \\
\hline 1182 & $1.52 \mathrm{E}-13$ & 2.2 & 1.32 & 1.541 & 0.703 & Triosephosphate isomerase \\
\hline 938 & $1.39 \mathrm{E}-11$ & 2.2 & 1.214 & 1.477 & 0.684 & Fructose-bisphosphate aldolase \\
\hline 951 & $3.83 \mathrm{E}-11$ & 2.2 & 1.113 & 1.454 & 0.67 & Fructose-bisphosphate aldolase \\
\hline 1017 & $3.84 \mathrm{E}-10$ & 2.1 & 1.002 & 1.367 & 0.653 & Glyceraldehyde-3-phosphate dehydrogenase \\
\hline 1011 & 4.09E-08 & 2.1 & 0.951 & 1.313 & 0.612 & Glyceraldehyde-3-phosphate dehydrogenase \\
\hline \multicolumn{7}{|c|}{ Group III: C>DV1 and DV3 } \\
\hline 1255 & $1.65 \mathrm{E}-12$ & 2.0 & 0.814 & 0.758 & 1.509 & Calponin \\
\hline 529 & $1.51 \mathrm{E}-10$ & 3.1 & 0.49 & 0.605 & 1.511 & Procollagen-lysine,2-oxoglutarate 5-dioxygenase \\
\hline 528 & $2.32 \mathrm{E}-13$ & 2.8 & 0.476 & 0.618 & 1.326 & Procollagen-lysine,2-oxoglutarate 5-dioxygenase \\
\hline 867 & $2.69 \mathrm{E}-10$ & 2.0 & 0.672 & 0.74 & 1.328 & Ethanolamine-phosphate cytidylyltransferase \\
\hline 442 & 9.77E-08 & 2.0 & 0.763 & 0.834 & 1.500 & Aconitase \\
\hline
\end{tabular}

with ER or mitochondrial stress [23,29]. In turn, the increase of chaperone proteins may also be due to the subversion of the cell by the virus in order to complete viral replication. Indeed, it has been demonstrated that flavivirus infection activates the key transcription factor of the UPR and take advantage of this cellular response to alleviate virus-induced cytotoxicity [37].

Chen et al. [23] further demonstrated that mosquito cells use antioxidant mechanisms to survive DENV infection. The changes in mitochondrial membrane potential and the generation of superoxide confirm that DENV induces oxidative stress in C6/36 cells [23]. This supports our results showing the overexpression in infected cells of quinone oxidoreductase, which is increasingly recognized as the major contributor to reactive oxygen species formation [38]. NADH quinone oxidoreductase catalyses $\mathrm{NADH}$ to $\mathrm{NAD}^{+}$, reduces ubiquinone, and transports protons across the inner mitochondrial membrane. This enzyme complex also reduces $\mathrm{O}_{2}$ to superoxide, which causes cellular oxidative stress [38]. This means that mosquito cells use the oxido-reduction mechanism to protect themselves against DENV viral infection.

Another interesting result of our study is that five enzymes involved in the glycolysis pathway were up-regulated. Increased glucose uptake and glycolytic enzyme activity due to viral infection have been found in other studies $[39,40]$. The induction of glycolytic proteins involved in energy production is also found in CHIKV and DENV2 infections [9]. Ritter et al. [18] suggested that the increased activity of glycolysis was due to the breakdown of the mitochondrial membrane, which decreased ATP concentration. As a result, the glycolysis pathway was activated to compensate for the lack of energy [18]. Recent studies have demonstrated more multifaceted functions of glycolytic enzymes such as GAPD and enolase. Both of these acquired non-glycolytic functions in transcriptional regulation. Moreover, GAPD might play a role as regulator or indicator of apoptosis [41]. Glycolysis is also reported to be the main source of energy production in Trypanosoma; this finding could represent a new drug target against parasites $[42,43]$. In addition, it has been reported that 
Table 2 Protein identification by MALDI-TOF MS

\begin{tabular}{|c|c|c|c|c|c|c|c|c|c|c|c|}
\hline $\begin{array}{l}\mathrm{N}^{\circ} \\
\text { spot } \\
\text { DIGE }\end{array}$ & $\begin{array}{l}\text { Entree } \\
\text { Swissprot_TrEMBL }\end{array}$ & Identification & $\begin{array}{l}\text { Biological } \\
\text { process }\end{array}$ & $\begin{array}{l}\text { Cellular } \\
\text { component }\end{array}$ & Molecular function & $\begin{array}{l}\text { Sequence } \\
\text { similarities }\end{array}$ & Pathway & $\begin{array}{l}\text { Molecular } \\
\text { mass (Da) }\end{array}$ & $\mathrm{pl}$ & $\begin{array}{l}\text { MASCOT } \\
\text { score }\end{array}$ & $\begin{array}{l}\text { Cover } \\
\text { sequence }\end{array}$ \\
\hline \multicolumn{12}{|c|}{ Protein up-regulated in infected cells } \\
\hline $978^{*}$ & Q17AU4_AEDAE & $\begin{array}{c}\text { Putative } \\
\text { uncharacterized } \\
\text { protein }\end{array}$ & & & & & & 42429 & 6.5 & 82 & 25 \\
\hline $663^{*}$ & Q16S95_AEDAE & $\begin{array}{l}\text { Quinone } \\
\text { oxidoreductase }\end{array}$ & $\begin{array}{l}\text { Oxidation } \\
\text { reduction }\end{array}$ & & $\begin{array}{l}\text { Oxidoreductase activity, zinc } \\
\text { ion binding }\end{array}$ & & & 50810 & 5.6 & 121 & 31 \\
\hline $\begin{array}{l}838^{\circ} \\
849^{\circ}\end{array}$ & Q17KK5_AEDAE & Enolase & Glycolysis & $\begin{array}{l}\text { Cell surface, } \\
\text { phosphopyru- } \\
\text { vate } \\
\text { hydratase } \\
\text { complex }\end{array}$ & $\begin{array}{l}\text { Magnesium ion binding, } \\
\text { phosphopyruvate hydratase } \\
\text { activity }\end{array}$ & $\begin{array}{l}\text { Belongs to the } \\
\text { enolase family. }\end{array}$ & $\begin{array}{l}\text { Carbohydrate } \\
\text { degradation, glycolysis, } \\
\text { pyruvate from D- } \\
\text { glyceraldehyde 3- } \\
\text { phosphate: step 4/5 }\end{array}$ & 46877 & 6.3 & 202 & 53 \\
\hline $\begin{array}{l}605^{\circ} \\
606^{\circ} \\
608^{\circ}\end{array}$ & BOWBF6_CULQU & $\begin{array}{c}\text { Putative } \\
\text { uncharacterized } \\
\text { protein }\end{array}$ & $\begin{array}{l}\text { Protein } \\
\text { folding }\end{array}$ & & $\begin{array}{l}\text { Chaperone, ATP binding, } \\
\text { unfolded protein binding }\end{array}$ & $\begin{array}{l}\text { Belongs to the } \\
\text { heat shock } \\
\text { protein } 70 \\
\text { family }\end{array}$ & & 72845 & 5.9 & 188 & 32 \\
\hline $\begin{array}{l}1150^{\circ}, \\
1153^{\circ}\end{array}$ & Q177P3_AEDAE & $\begin{array}{l}\text { Phosphoglycerate } \\
\text { mutase }\end{array}$ & Glycolysis & & $\begin{array}{c}\text { 2,3-bisphosphoglycerate- } \\
\text { dependent phosphoglycerate } \\
\text { mutase activity }\end{array}$ & & & 28582 & 6.6 & 131 & 41 \\
\hline $\begin{array}{l}1181^{\circ}, \\
1182^{\circ}\end{array}$ & Q17HW3_AEDAE & $\begin{array}{l}\text { Triosephosphate } \\
\text { isomerase }\end{array}$ & Glycolysis & & $\begin{array}{l}\text { Isomerase, triose-phosphate } \\
\text { isomerase activity }\end{array}$ & $\begin{array}{l}\text { Belongs to the } \\
\text { triosephosphate } \\
\text { isomerase family }\end{array}$ & $\begin{array}{c}\text { Carbohydrate } \\
\text { biosynthesis, } \\
\text { gluconeogenesis, } \\
\text { carbohydrate } \\
\text { degradation, glycolysis, } \\
\text { D-glyceraldehyde 3- } \\
\text { phosphate from } \\
\text { glycerone phosphate: } \\
\text { step } 1 / 1\end{array}$ & 26705 & 6 & 161 & 44 \\
\hline $\begin{array}{l}935^{\circ} \\
938^{\circ} \\
951^{\circ}\end{array}$ & Q178U8_AEDAE & $\begin{array}{l}\text { Fructose- } \\
\text { bisphosphate } \\
\text { aldolase }\end{array}$ & Glycolysis & & $\begin{array}{l}\text { Fructose-bisphosphate aldolase } \\
\text { activity }\end{array}$ & $\begin{array}{l}\text { Belongs to the } \\
\text { class I fructose- } \\
\text { bisphosphate } \\
\text { aldolase family. }\end{array}$ & $\begin{array}{c}\text { Carbohydrate } \\
\text { degradation, glycolysis, } \\
\text { D-glyceraldehyde 3- } \\
\text { phosphate and } \\
\text { glycerone phosphate } \\
\text { from D-glucose: step 4/ } \\
4\end{array}$ & 39551 & 8 & 172 & 50 \\
\hline $716^{\circ}$ & Q16PM9_AEDAE & Chaperonin-60kD & $\begin{array}{l}\text { Protein } \\
\text { refolding }\end{array}$ & Cytoplasm & $\begin{array}{l}\text { ATP binding, unfolded protein } \\
\text { binding, chaperone }\end{array}$ & $\begin{array}{l}\text { Belongs to the } \\
\text { chaperonin } \\
\text { (Hsp60) family }\end{array}$ & & 61155 & 5.5 & 75 & 20 \\
\hline $\begin{array}{l}1011^{\circ} \\
1017^{\circ}\end{array}$ & BOWEB5_CULQU & $\begin{array}{l}\text { Glyceraldehyde-3- } \\
\text { phosphate } \\
\text { dehydrogenase }\end{array}$ & $\begin{array}{l}\text { Glycolysis, } \\
\text { oxidation } \\
\text { reduction }\end{array}$ & Cytoplasm & $\begin{array}{c}\text { NAD or NADH binding, } \\
\text { glyceraldehyde-3-phosphate } \\
\text { dehydrogenase } \\
\text { (phosphorylating) activity }\end{array}$ & $\begin{array}{c}\text { Belongs to the } \\
\text { glyceraldehyde- } \\
\text { 3-phosphate } \\
\text { dehydrogenase } \\
\text { family }\end{array}$ & $\begin{array}{c}\text { Carbohydrate } \\
\text { degradation, glycolysis, } \\
\text { pyruvate from D- } \\
\text { glyceraldehyde 3- } \\
\text { phosphate: step 1/5 }\end{array}$ & 35693 & 8.5 & 114 & 40 \\
\hline
\end{tabular}


Table 2 Protein identification by MALDI-TOF MS (Continued)

\begin{tabular}{|c|c|c|c|c|c|c|c|c|}
\hline \multicolumn{9}{|c|}{ Protein up-regulated in non-infected cells } \\
\hline $1255^{\#}$ & Q1HR19_AEDAE & Calponin & & & 20936 & 8.3 & 183 & 73 \\
\hline $\begin{array}{l}528^{\# \prime} \\
529^{\#}\end{array}$ & QOIER9_AEDAE & $\begin{array}{l}\text { Procollagen- } \\
\text { lysine,2- } \\
\text { oxoglutarate 5- } \\
\text { dioxygenase }\end{array}$ & $\begin{array}{l}\text { Oxidation } \\
\text { reduction }\end{array}$ & $\begin{array}{l}\text { L-ascorbic acid binding, iron } \\
\text { ion binding, oxidoreductase } \\
\text { activity acting on paired } \\
\text { donors with incorporation or } \\
\text { reduction of molecular oxygen, } \\
\text { oxidoreductase activity acting } \\
\text { on single donors with } \\
\text { incorporation of molecular } \\
\text { oxygen, incorporation of two } \\
\text { atoms of oxygen }\end{array}$ & 82324 & 5.7 & 202 & 25 \\
\hline $867^{\#}$ & Q179F9_AEDAE & $\begin{array}{l}\text { Ethanolamine- } \\
\text { phosphate } \\
\text { cytidylyltransferase }\end{array}$ & $\begin{array}{l}\text { Biosynthetic } \\
\text { process }\end{array}$ & Nucleotidyltransferase activity & 42278 & 6.1 & 102 & 23 \\
\hline $442^{\#}$ & Q16ZG5_AEDAE & Aconitase & $\begin{array}{l}\text { Metabolic } \\
\text { process }\end{array}$ & 4 iron, 4 sulfur cluster binding & 99252 & 5.8 & 165 & 23 \\
\hline
\end{tabular}

Symbol : * represents proteins that are up-regulated in cells infected by DENV-1, ${ }^{\circ}$ represents proteins that are up-regulated in cells infected by DENV-3 and ${ }^{*}$ represents proteins that are up-regulated in mockinfected cells. 
GAPDH binds to the minus-strand RNAs of Japanese encephalitis virus and the subcellular localization of GAPDH changed upon JEV infection, suggesting that GAPDH may play a role during the virus life cycle [44]. These evidences suggest that blocking the glycolysis pathway could constitute a new tool in the fight against mosquito-borne diseases via their vector control. The increase in glycolytic enzymes could also be a result of the arrest at the G1 cell cycle due to UPR.

\section{Conclusions}

The modulation of protein expression found in our study might be the strategy of the virus to overcome host pathways to facilitate survival at the expense of the host. Further studies are needed to understand the mechanism by which these proteins are induced during viral infection. Virus could stimulate the transcription and translation of some host products for their survival, but the mechanism is still unknown. The modulation of protein expression could also be the mosquito's response to the viral infection. It would be interesting in a further study, to determine whether a similar response occurs in cells infected with another virus or if the observed modulation of protein expression is specifically induce in response to DENV infection. Mosquitoes generate oxido-reduction stress to cope with the virus and stimulate the glycolysis pathway to prevent cellular damage. Thus, it might be beneficial to understand the proteome of infected cells to develop an anti-pathogen approach. However, these proteomics studies need to be complemented by studies using RNAi gene silencing to allow the characterization of modulated genes in vivo in mosquito tissues. Improvements in our knowledge on mosquito cell systems will be important to decipher the infection process of dengue virus in human.

\section{Methods}

\section{Cell culture and virus infection}

Ae. Albopictus C6/36 cells were grown in minimal essential medium supplemented with $10 \%$ fetal calf serum, $1 \%$ L-glutamine, $1 \%$ sodium bicarbonate, $1 \%$ nonessential amino acids, $50 \mathrm{U} / \mathrm{mL}$ of penicillin, and $50 \mu \mathrm{g} / \mathrm{mL}$ of streptomycin at $28^{\circ} \mathrm{C}$ [45]. Cells were infected with two serotypes of Dengue virus, DENV-1 (Hawaii strain) and DENV-3 (H87 strain), at an multiplicity of infection of 0.01 then incubated at $28^{\circ} \mathrm{C}$ for 48 hours [17]. Mockinfected cells were used as the normal physiological control and represent cells incubated with supernatant of uninfected $\mathrm{C6} / 36$. The experiment was done in quadruplicate. The DENV-1 and DENV-3 virus stocks were propagated in C6/36 Ae. albopictus cells.

\section{Protein sample preparation}

Infected or mock-infected cells were washed with PBS and then lysed by solubilizing buffer (7 M urea, $2 \mathrm{M}$ thiourea, 4\% CHAPS, $0.5 \%$ Triton X-100, and $40 \mathrm{mM}$ Tris-HCl). After a centrifugation at $16000 \times \mathrm{g}$ for 45 min, the supernatants were collected and protein concentrations were measured using a 2-D Quant kit (GE Healthcare).

\section{D-DIGE, image scanning, and statistical analysis}

For analytical 2D-DIGE, DENV-1 and DENV-3 infected and non-infected protein samples were compared using the CyDye DIGE Fluors for Ettan DIGE (Cy2, Cy3, and Cy5). Proteins were labelled according to the Ettan DIGE minimal labelling protocol (Ettan DIGE User Manual, GE Healthcare). For each sample (DENV-1, DENV-3 or mock-infected protein samples), $50 \mu \mathrm{g}$ of protein was labeled with 400 pmol of either Cy3 or Cy5. The internal standard was a pool of equal amounts $(25 \mu \mathrm{g})$ from all samples which was labeled with Cy2. These labeled samples were then combined and loaded on gels. Every gels contained $50 \mu \mathrm{g}$ of sample labeled with Cy3, $50 \mu \mathrm{g}$ of sample labeled with Cy5 and $50 \mu \mathrm{g}$ of internal standard labeled with $\mathrm{Cy} 2$. The sample volume was made up to $450 \mu \mathrm{L}$ by adding rehydration buffer $(7 \mathrm{M}$ urea, $2 \mathrm{M}$ thiourea, 4\% CHAPS, 0.5\% Triton X-100, 40 mM Tris$\mathrm{HCl}, 1 \%$ IPG buffer, and 1.2\% DeStreak) prior to separation by isoelectric focusing (IEF). IEF was performed with 24 cm Immobiline DryStrip, pH 3-10 NL. The run conditions were as follows: rehydration for $14 \mathrm{~h}$ at $20^{\circ} \mathrm{C}$, current of $50 \mu \mathrm{A}$ per strip, $60 \mathrm{~V}$ (step) for $3 \mathrm{~h}, 1000 \mathrm{~V}$ (gradient) for $4 \mathrm{~h}, 8000 \mathrm{~V}$ (gradient) for $4 \mathrm{~h}$, and $8000 \mathrm{~V}$ (step) until reaching a total of $64000 \mathrm{Vh} .2$-DE was performed on 12\% SDS-PAGE gel at $15 \mathrm{~mA} /$ gel for $6 \mathrm{~h}$ and then at $30 \mathrm{~mA} / \mathrm{gel}$ until the bromophenol blue front reached the end of the gel. Gels were scanned using a Typhoon 9400 imager (Amersham Biosciences). All gel images were acquired at $100 \mu \mathrm{m}$ pixel resolution under nonsaturating conditions. 2D-DIGE images were analyzed using Progenesis SameSpots 3.1 software. Statistical analysis and protein quantification were carried out using this software with ANOVA which took into account the mean difference and the variance among 3 groups: DENV-1, DENV-3 and mock-infected groups. The fold change with a cut-off of 2.0-fold up- or down-regulated was used (calculated between the lowest mean normalised volume and the highest mean normalised volume of each spot). The statistical power of this study was greater than 0.8. Protein spots with a significant altered expression $(\mathrm{p}<0.001)$ were trypsin digested and identified with mass spectrometry.

\section{Protein identification by MALDI-TOF MS}

For 2D-DIGE, gels were run with $150 \mu \mathrm{g}$ of a mix of protein from the different samples $(50 \mu \mathrm{g}$ of each sample labeled with $\mathrm{Cy} 3, \mathrm{Cy} 5$ and $\mathrm{Cy} 2$ ) and these gels were afterwards stained with CBB. Spots of interest were 
localized on the gels by comparing the CBB-stained spot pattern with the 2D-DIGE protein pattern. To ensure consistency, gels were analysed using Progenesis SameSpots 3.1 software and differential spots were identified. Gel image containing differential spots and picking gels were compared physically side-by-side and the candidate spots were excised manually in a laminar flow hood. Enzymatic in-gel digestion through peptide spotting and protein identification was performed as previously described [46,47]. Briefly, protein spots were digested using $150 \mathrm{ng}$ of trypsin, peptide extraction was performed using five sonication cycles of $2 \mathrm{~min}$ each, and peptides were concentrated $1 \mathrm{~h}$ at $50^{\circ} \mathrm{C} ; 0.5 \mu \mathrm{L}$ of sample peptide and $0.5 \mu \mathrm{L}$ of CHCA were deposited on a 384-well MALDI anchorship target using the dry-droplet procedure. Peptide samples were then desalted on the target using a $10 \mathrm{mM}$ phosphate buffer. Analyses were performed using an UltraFlex I MALDI TOF-TOF mass spectrometer (Bruker Daltonics, Bremen, Germany) in the reflectron mode with a $26 \mathrm{kV}$ accelerating voltage and a $50 \mathrm{~ns}$ delayed extraction. Mass spectra were acquired manually or in the automatic mode using the AutoXecute module of Flexcontrol (Bruker Daltonics) (laser power ranged from 30 to $50 \%, 600$ shots). Spectra were analyzed using FlexAnalysis software (Bruker Daltonics) and calibrated internally with the autoproteolysis peptides of trypsin (m/z 842.51, 1045.56, 2211.10). Peptides were selected in the mass range of 900-3000 Da. Peptide Mass Fingerprint identification of proteins was performed by searching against the Insecta entries of either the Swiss-Prot or TrEMBL databases http://www.expasy.ch and by using the MASCOT v 2.2 algorithm (http://www.matrixscience.com) with trypsin enzyme specificity and one trypsin missed cleavage allowed [48]. Carbamidomethyl was set as fixed cystein modification and oxidation was set as variable methionine modification for searches. A mass tolerance of 50 ppm was allowed for identification. Matching peptides with one missed cleavage were considered as pertinent when there were two consecutive basic residues or when arginine and lysine residues were in an acidic context. MASCOT scores higher than 65 were considered as significant $(\mathrm{p}<0.05)$ for Swiss-Prot and TrEMBL database interrogations.

\footnotetext{
List of abbreviations used

Dengue Virus: DENV; Aedes: Ae; Japanese encephalitis virus: JEV; DHF: Dengue Hemorrhagic Fever; GAPDH: glyceraldehyde-3-phosphate dehydrogenase; UPR: Unfolded protein response; PLOD: Procollagen-lysine 2oxyglutarate 5-dioxygenase; HSP: Heat shock protein; MALDI-TOF MS: Matrix assisted laser desorption ionisation time-of-flight mass spectrometry.
}

\section{Acknowledgements and Funding}

We are grateful to David Biron for insightful discussions. This work was supported by grants from Agence Nationale de Recherche (ANR BLANC) and
CNRS Interdisciplinaire MIE, France and the Trop.Med Grants, Faculty of Tropical Medicine, Bangkok, Thailand.

\section{Author details}

'Laboratoire Maladies Infectieuses et Vecteurs: Ecologie, Génétique, Evolution, Contrôle., UMR 5290 CNRS/RDD/UM1, Montpellier, France. ${ }^{2}$ Department of Tropical Hygiene, Faculty of Tropical Medicine, Mahidol University, Bangkok, Thailand. ${ }^{3}$ Plate-forme de Protéomique Fonctionnelle, IFR3, CNRS-UMR 5203, INSERM-U661, UMI-II, 34094 Montpellier France. ${ }^{4}$ Unité de Génétique Moléculaire des Bunyavirus, Institut Pasteur, Paris, France.

\section{Authors' contributions}

Conceived and designed the experiments: SP, DM. Performed the experiments: SP, PS, MS. Analyzed the data: SP, PS, DM. Wrote the paper: SP, DM. Corrected the manuscript: VC, FT. All authors read approved the final version of the MS

\section{Competing interests}

The authors declare that they have no competing interests.

Received: 14 May 2011 Accepted: 18 July 2011 Published: 18 July 2011

\section{References}

1. Lambrechts L, Scott TW, Gubler DJ: Consequences of the expanding global distribution of Aedes albopictus for dengue virus transmission. PLoS Negl Trop Dis 2010, 4(5):e646.

2. La Ruche G, Souares Y, Armengaud A, Peloux-Petiot F, Delaunay P, Despres $P$, Lenglet A, Jourdain F, Leparc-Goffart I, Charlet F, Ollier L, Mantey K, Mollet T, Fournier JP, Torrents R, Leitmeyer K, Hilairet P, Zeller $H$, Van Bortel W, Dejour-Salamanca D, Grandadam M, Gastellu-Etchegorry M: First two autochthonous dengue virus infections in metropolitan France. Euro Surveill 2010, 15:19676.

3. Weaver SC, Reisen WK: Present and future arboviral threats. Antiviral Res 2010, 85:328-345.

4. Paupy C, Delatte H, Bagny L, Corbel V, Fontenille D: Aedes albopictus, an arbovirus vector: from the darkness to the light. Microbes Infect 2009, 11:1177-1185.

5. World Health Organization (WHO): Impact of dengue. Geneva: WHO; [http://www.who.int/csr/disease/dengue/impact/en/index.html], (Accessed 27 Sep 2010).

6. Franco L, Di Caro A, Carletti F, Vapalahti O, Renaudat C, Zeller H, Tenorio A: Recent expansion of dengue virus serotype 3 in West Africa. Euro Surveill 2010, 15:19490.

7. Ross TM: Dengue virus. Clin Lab Med 2010, 30:149-160.

8. Vazquez-Prokopec GM, Kitron U, Montgomery B, Horne P, Ritchie SA: Quantifying the spatial dimension of dengue virus epidemic spread within a tropical urban environment. PLoS Negl Trop Dis 2010, 4(12): e920.

9. Tchankouo-Nguetcheu S, Khun H, Pincet L, Roux P, Bahut M, Huerre M, Guette C, Choumet V: Differential protein modulation in midguts of Aedes aegypti infected with chikungunya and dengue 2 viruses. PLOS One 2010, 5:e13149.

10. Gautret P, Botelho-Nevers E, Charrel RN, Parola P: Dengue virus infections in travellers returning from Benin to France, July-August 2010. Euro Surveill 2010, 15:19657.

11. Vaughn DW: Invited commentary: Dengue lessons from Cuba. Am J Epidemiol 2000, 152:800-803.

12. Vaughn DW, Green S, Kalayanarooj S, Innis BL, Nimmannitya S, Suntayakorn S, Endy TP, Raengsakulrach B, Rothman AL, Ennis FA, Nisalak A: Dengue viremia titer, antibody response pattern, and virus serotype correlate with disease severity. I Infect Dis 2000, 181:2-9.

13. Fried JR, Gibbons RV, Kalayanarooj S, Thomas SJ, Srikiatkhachorn A, Yoon IK, Jarman RG, Green S, Rothman AL, Cummings DA: Serotype-Specific Differences in the Risk of Dengue Hemorrhagic Fever: An Analysis of Data Collected in Bangkok, Thailand from 1994 to 2006. PLoS Negl Trop Dis 2010, 4(3):e617.

14. Murphy BR, Whitehead SS: Immune response to dengue virus and prospects for a vaccine. Annu Rev Immunol 2011, 29:587-619.

15. Nisii C, Carletti F, Castilletti C, Bordi L, Meschi S, Selleri M, Chiappini R, Travaglini D, Antonini M, Castorina S, Lauria FN, Narciso P, Gentile M, Martini L, Di Perri G, Audagnotto S, Biselli R, Lastilla M, Di Caro A, 
Capobianchi M, Ippolito G: A case of dengue type 3 virus infection imported from Africa to Italy. Euro Surveill 2010, 15:19487.

16. Halstead SB: Dengue virus-mosquito interactions. Annu Rev Entomol 2008, 53:273-291.

17. Sakoonwatanyoo P, Boonsanay V, Smith DR: Growth and production of the dengue virus in C6/36 cells and identification of a laminin-binding protein as a candidate serotype 3 and 4 receptor protein. Intervirology 2006, 49:161-172.

18. Ritter JB, Wahl AS, Freund S, Genzel Y, Reichl U: Metabolic effects of influenza virus infection in cultured animal cells: Intra- and extracellular metabolite profiling. BMC Syst Biol 2010, 4:61.

19. Kikuchi $Y$, Suzuki $Y$, Tamiya N: The source of oxygen in the reaction catalysed by collagen lysyl hydroxylase. Biochem J 1983, 213:507-512.

20. Winder SI, Walsh MP: Smooth muscle calponin. Inhibition of actomyosin MgATPase and regulation by phosphorylation. Biochem Int 1990, 22:335-341.

21. Kent C: CTP:phosphocholine cytidylyltransferase. Biochim Biophys Acta 1997, 1348:79-90.

22. Tong $\mathrm{WH}$, Rouault TA: Metabolic regulation of citrate and iron by aconitases: role of iron-sulfur cluster biogenesis. Biometals 2007, 20:549-564.

23. Chen TH, Tang P, Yang CF, Kao LH, Lo YP, Chuang CK, Shih YT, Chen WJ: Antioxidant defense is one of the mechanisms by which mosquito cells survive dengue 2 viral infection. Virology 2011, 410:410-417.

24. Xi Z, Ramirez JL, Dimopoulos G: The Aedes aegypti toll pathway controls dengue virus infection. PLOS Pathog 2008, 4:e1000098.

25. Luplertlop N, Surasombatpattana P, Patramool S, Dumas E, Wasinpiyamongkol L, Saune L, Hamel R, Bernard E, Sereno D, Thomas F, Piquemal D, Yssel H, Briant L, Missé D: Induction of a peptide with activity against a broad spectrum of pathogens in the Aedes aegypti salivary gland, following Infection with dengue virus. PLOS Pathog 2011, 7 e1001252.

26. Sanchez-Vargas I, Scott JC, Poole-Smith BK, Franz AWE, Barbosa-Solomieu V, Wilusz J, Olson KE, Blair CD: Dengue virus type 2 infections of Aedes aegypti are modulated by the mosquito's RNA interference pathway. PLOS Pathog 2009, 5:e1000299.

27. Souza-Neto JA, Sim S, Dimopoulos G: An evolutionary conserved function of the JAK-STAT pathway in anti-dengue defense. Proc Natl Acad Sci USA 2009, 106:17841-17846.

28. Malik A, Earhart K, Mohareb E, Saad M, Saeed M, Ageep A, Soliman A: Dengue hemorrhagic fever outbreak in children in Port Sudan. $J$ Infect Public Health 2011, 4:1-6.

29. Yoshida H: ER stress response, peroxisome proliferation, mitochondrial unfolded protein response and Golgi stress response. IUBMB Life 2009, 61:871-879.

30. Ellis RJ: Molecular chaperones: assisting assembly in addition to folding. Trends Biochem Sci 2006, 31:395-401.

31. Carvalho MG, Fournier MV: Effect of heat shock on gene expression of Aedes albopictus cells infected with Mayaro virus. Res Virol 1991, 142:25-31.

32. Hu JM, Seager C: Hsp90 is required for the activity of hepatitis B virus reverse transcriptase. Proc Natl Acad Sci USA 1996, 93:1060-1064.

33. Santoro MG: Heat shock proteins and virus replication: hsp70s as mediators of the antiviral effects of prostaglandins. Experientia 1994, 50:1039-1047.

34. Maguire M: Chaperonin 60 unfolds its secrets of cellular communication. Cell Stress Chap 2002, 7:317-329.

35. Mayer MP, Bukau B: Hsp70 chaperones: cellular functions and molecular mechanism. Cell Mol Life Sci 2005, 62:670-684.

36. Mery L, Mesaeli N, Michalak M, Opas M, Lew DP, Krause KH: Overexpression of calreticulin increases intracellular Ca2+ storage and decreases store-operated Ca2+ influx. J Biol Chem 1996, 271:9332-9339.

37. Yu CY, Hsu YW, Liao CL, Lin YL: Flavivirus infection activates the XBP1 pathway of the unfolded protein response to cope with endoplasmic reticulum stress. J Virol 2006, 80:11868-11880.

38. Hirst J: Towards the molecular mechanism of respiratory complex I. Biochem J 2009, 425:327-339.

39. Klemperer $\mathrm{H}$ : Glucose breakdown in chick embryo cells infected with influenza virus. Virology 1961, 13:68-77.

40. El-Bacha T, Menezes MM, Azevedo e Silva MC, Sola-Penna M, Da Poian AT: Mayaro virus infection alters glucose metabolism in cultured cells through activation of the enzyme 6-phosphofructo 1-kinase. Mol Cell Biochem 2004, 266:191-198.

41. Kim JW, Dang CV: Multifaceted roles of glycolytic enzymes. Trends Biochem Sci 2005, 30:142-150.

42. Verlinde $C L$, Hannaert $V$, Blonski $C$, Willson M, Périé JJ, Fothergill-Gilmore LA Opperdoes FR, Gelb MH, Hol WG, Michels PA: Glycolysis as a target for the design of new anti-trypanosome drugs. Drug Resist Updat 2001, 4:50-65.

43. Cáceres AJ, Michels PA, Hannaert V: Genetic validation of aldolase and glyceraldehyde-3-phosphate dehydrogenase as drug targets in Trypanosoma brucei. Mol Biochem Parasitol 2010, 69:50-54.

44. Yang SH, Liu ML, Tien CF, Chou SJ, Chang RY: Glyceraldehyde-3phosphate dehydrogenase (GAPDH) interaction with 3 ' ends of Japanese encephalitis virus RNA and colocalization with the viral NS5 protein. J Biomed Sci 2009, 16:40.

45. Igarashi A: Isolation of a Singh's Aedes albopictus cell clone sensitive to Dengue and Chikungunya viruses. J Gen Virol 1978, 40:531-544.

46. Thomas F, Ravel S, Patrel D, Renault L, Le Bourligu L, Cuny G, Biron DG: Trypanosoma brucei brucei induces alteration in the head proteome of the tsetse fly vector Glossina palpalis gambiensis. Insect Mol Biol 2007, 16:651-660.

47. Wasinpiyamongkol L, Patramool S, Luplertlop N, Surasombatpattana P, Doucoure S, Mouchet F, Séveno M, Remoue F, Demettre E, Brizard JP, Jouin P, Biron DG, Thomas F, Missé D: Blood-feeding and immunogenic Aedes aegypti saliva proteins. Proteomics 2010, 10:1906-1916.

48. Wilkins MR, Williams KL: Cross-species protein identification using amino acid composition, peptide mass fingerprinting, isoelectric point and molecular mass: a theoretical evaluation. J Theor Biol 1997, 186:7-15.

doi:10.1186/1756-3305-4-138

Cite this article as: Patramool et al:: Proteomic analysis of an Aedes albopictus cell line infected with Dengue serotypes 1 and 3 viruses. parasites \& Vectors 2011 4:138.

\section{Submit your next manuscript to BioMed Central and take full advantage of:}

- Convenient online submission

- Thorough peer review

- No space constraints or color figure charges

- Immediate publication on acceptance

- Inclusion in PubMed, CAS, Scopus and Google Scholar

- Research which is freely available for redistribution

Submit your manuscript at www.biomedcentral.com/submit
C Biomed Central 